\title{
Trade Agreements and Export Creation: An Empirical Analysis of Pakistan's Exports at Industry Level
}

\author{
Tehseen Ahmed Qureshi* and Anwar Shah"*
}

\begin{abstract}
This paper examines patterns of export creation and diversion by analyzing Pakistan's trade agreements at the two-digit industry level for all 88 export-oriented industries. We compare the net change in exports with nine free trade agreement (FTA) partners and the top 15 partners with most-favored nation (MFN) status. We find that 45 industries account for USD4.1 billion in export creation across all Pakistan's FTA partners. Here, net exports increase after FTAs with both FTA and MFN partners. Conversely, export diversion worth USD137 million occurs in 10 industries with all FTA partners as net exports to FTA partners rise while net exports to MFN partners fall. In the same manner, we find that net exports in 33 industries declined by USD500 million with FTA and MFN partners. The total net exports addition after FTAs was USD3.5 billion or, on average, USD350 million annually, accounting for about 1.4 percent of Pakistan's total annual goods exports. On average, Pakistan has successfully created exports in half its export-oriented industries, although highly subsidized industries exhibit either export diversion or a net decline with both MFN and FTA partners. A difference-in-difference analysis shows that exports to China and Mauritius rose significantly while the remaining seven FTA partners did not have a significant increase in exports after the FTAs were implemented. In view of these findings, we suggest revisiting the policy of export subsidies.
\end{abstract}

Keywords: Free trade agreements, export creation, export diversion, industries.

JEL Classification: F1, F14, F68.

\section{Introduction}

Pakistan's export performance has remained sluggish over the past decade, with a modest 27 percent rise in exports during 2005-16 in contrast

\footnotetext{
* Tehseen Ahmed is a PhD candidate at the School of Economics, Quaid-i-Azam University, Islamabad, Pakistan.

** Associate Professor, School of Economics, Quaid-i-Azam University, Islamabad, Pakistan.
} 
to countries such as India, Bangladesh and Vietnam that increased their exports by 165, 276 and 445 percent, respectively. ${ }^{1}$ In 2013, Pakistan's exports in goods were recorded at USD25 billion, but by 2017, they had fallen to USD22 billion. On the imports side, Pakistan has been unable to slow down their constant rise and, as a result, the trade deficit has soared to USD31 billion in 2017 or 10 percent of GDP. ${ }^{2}$

The swelling trade deficit has resulted in various export promotion policies over the years, including bilateral and multilateral trade agreements; subsidies for major export industries such as concessional utility tariffs, sales tax refunds, and concessional interest rates; and the imposition of higher import tariffs and federal excise duties on consumer items. However, on average, these incentives have failed to have a significant impact on the growth of exports (Ahmed, Hamid \& Mahmud, 2013). This study attempts to evaluate the free trade agreements (FTAs) and preferential trade agreements (PTAs) implemented by Pakistan.

Numerous studies have focused on the issues of trade diversion and trade creation through FTAs, PTAs and customs unions, including work by Frankel and Wei (1995), Yeats (1998), Magee (2008), and Akhter and Ghani (2010). Caliendo and Parro (2015) and Felbermayr et al. (2015) have worked on the general equilibrium effects of trade creation and diversion by estimating the welfare changes to producers and consumers. A major weakness of computable general equilibrium models are their complexity, which makes them nontransparent. Simulating an economic system means making many choices that affect the outcome. It is sometimes difficult to justify them, and questions arise as to how such choices can be linked to policy changes (Magee, 2016; Sorgho, 2016).

There is a caveat to the trade creation narrative: An FTA deemed successful in increasing exports may actually lead to declining exports with nonmember countries. This decrease in exports may even surpass the increase in exports with FTA partners. However, government agencies reviewing the FTA may only be examining the trend in exports to FTA partners. Such reviews neglect export trends with nonmember countries. The key reason for signing an FTA is that the economy aims at earnings through exports. If the increased exports from an industry in the home country to a member country are being diverted from nonmember countries,

\footnotetext{
${ }^{1}$ Data from the World Development Indicators database for 2016.

${ }^{2}$ Data for 2018 from the State Bank of Pakistan.
} 
then no new foreign exchange is flowing in (Soloaga \& Winters, 2001). This is the intuition underlying our study-to examine whether Pakistan's FTAs have brought in new foreign income to the country.

There are two main research gaps. First, the bulk of research carried out has been on the welfare effects, focusing on whether FTAs favor or harm low-cost producers. There has been little research on whether FTAs are a way of enhancing export income through concessional trade. Second, earlier research has focused on the econometric significance of trade creation or trade diversion variables rather than the net export creation and diversion by determining the change in value of net exports after signing FTAs with member countries vis-à-vis the change in exports to nonmember countries during the same period.

Pakistan currently enjoys free or preferential trade access with 11 of its trading partners under the following seven agreements: (a) South Asian Free Trade Agreement (SAFTA) (2006), comprising India, Bangladesh, Sri Lanka, the Maldives, Nepal and Bhutan; (b) PakistanMalaysia FTA (2008); (c) Pakistan-China FTA (2007); (d) Pakistan-Iran PTA; (e) Pakistan-Indonesia PTA (2012); and (f) Pakistan-Mauritius PTA (2007). Data on Pakistan's bilateral trade with Nepal and Bhutan is, however, largely unavailable. We examine whether these trade agreements have been able to create new exports in value for Pakistan or if they have diverted exports from partners with most-favored nation (MFN) status. If the latter is true, we could argue that the FTAs and PTAs did not create new exports or bring in higher foreign exchange.

The study is divided into six sections. Section 2 discusses our theoretical framework. Section 3 discusses the empirical literature and gaps on the issue of trade creation and diversion. Section 4 presents the data and methodology applied. Section 5 details our findings and results. Section 6 concludes the paper and presents policy implications.

\section{Theoretical Framework}

In Bentick's (1963) three-country model, all three have similar levels of economic development. Countries A and B decide to sign an FTA in which both will maintain a protective tariff against the third country, $C$. It is assumed that the governments of $\mathrm{A}$ and $\mathrm{B}$ (a) are aware of the production costs involved, and (b) compare their own production costs with the production costs of $\mathrm{C}$ as a criterion for tariff adjustment. 
Let us consider the example of textiles. Country A levies a 30 percent tariff while country B imposes a 20 percent tariff against textile imports from C. We can infer that A's cost of production (for textiles) is at least 30 percent more than that of $C$, while $\mathrm{B}^{\prime}$ s cost of production is at least 20 percent higher than that of $C$. Therefore, $A^{\prime} s$ cost of production is 10 percent more than that of $B$. In the scenario of free trade between $A$ and $B$, textiles will be exported by $\mathrm{B}$ to $\mathrm{A}$. Thus, exports will be created in all those commodities for which the tariffs of A and B are different for C. B will export all those commodities to A for which its tariff is lower than that of $A$ and vice versa.

This implies that, when a country imposes tariffs on the import of a commodity, it is assumed that the domestic cost of production for that commodity is higher in that country and that, to protect domestic producers, low-cost imports after tariffs are sold at the same price or higher as the domestically produced commodity. Therefore, exports between member countries will be greater for those commodities in which each member has a competitive advantage and this will reduce exports to nonmember countries, causing export diversion. However, if A does not impose any tariff on $\mathrm{C}$ for a given commodity, for example, footwear, but $B$ imposes a 10 percent tariff on footwear for $C$, we can assume that the cost of producing footwear in $\mathrm{A}$ is lower than that of $\mathrm{B}$ as well as $\mathrm{C}$. In this scenario, the exports of a low-cost producer of footwear, A, will not be affected by imports from $C$ and will increase for $B$. If exports to nonmember countries are not affected and exports to member countries increase, then we call this export creation.

\section{Review of the Literature}

Tinbergen (1962) pioneered use of the gravity model and found a significant increase in trade between Commonwealth countries. Viner (1950) examined whether trade agreements were responsible for a shift in imports from low-cost nonmembers to high-cost members, and for a shift from reliance on high-cost domestic production to low-cost imports from member countries. The gravity model became more robust in the 1970s and 1980s when it was suggested that physical distance was not the only determinant but that many other unobserved and observed variables contributed to bilateral and multilateral trade flows.

The extended gravity model was applied by Aitken (1973) and Brada and Mendez (1983) to the Latin American Free Trade Association and European Free Trade Association (EFTA) by adding a dummy variable $\left(F T A_{i j t}\right)$ for whether both countries fall under the same FTA during one 
period, and another dummy $\left(F T A_{i t}\right)$ if only one partner has joined the FTA in that period. If $F T A_{i j t}$ has a positive sign, this implies trade creation between FTA members, while a negative coefficient for $F T A_{i t}$ implies trade diversion. This dummy variable methodology is still widely used to determine trade creation and diversion under various trade agreements.

Application of the gravity model has generated inconclusive results in certain cases: some studies have found FTAs such as the North American Free Trade Agreement (NAFTA), Mercosur, ASEAN, and the European Union Customs Union to be trade creating (see Bergstrand, 2002; Carrere, 2003), while others have found the same FTAs to be trade diverting (see Chor, 2010; Costinot, Donaldson \& Komunjer, 2012; Donaldson, 2012; Wei \& Frankel, 1995). The main criticism of the gravity model is that including dummy variables catches the range of other variables that may have helped initiate the FTA, but which are not included in the model. In addition, there remains a reverse casualty bias in gravity model estimates, as economies with higher levels of trade are more likely to engage in bilateral or regional agreements. Hence, the error term becomes correlated with the FTA dummy variable, inducing the problem of endogeneity (Baier \& Bergstrand, 2007; Magee, 2008, 2016).

The literature on the impact of FTAs on exports is very limited. Freund and Ornelas (2010) discuss the importance of including exports in trade creation and diversion analysis and add an exports variable to the gravity model to assess whether inclusion in an FTA causes exports to be more than they would in the absence of such an agreement. Their sample includes data from 1948 to 2000, covering a large range of FTAs. The EC, NAFTA, Mercosur and AFTA results show that all FTAs caused countries to export more than they would have in the case of no agreement. These results imply that agreements between richer countries are more successful while agreements between low-income and lower middle-income countries are more or less a failure and may even have adverse results.

Soloaga and Winters (2001) apply the dummy variable gravity model to estimate the impact of FTAs on the exports and imports of 58 countries under various trade agreements. They find evidence of export diversion in the EU and EFTA, but do not explore export creation.

The impact of trade agreements is not just associated with imports from member and nonmember countries or the world's welfare gain and loss from FTAs. It is equally important to understand how bilateral and regional trade agreements contribute to the broader approach of openness 
and whether they provide a stimulus for local exporters to capture larger shares in the world export market. Interestingly, while there are studies on the success of FTAs that estimate the gain in exports before and after member countries implement the FTA, trade creation and diversion effects from an exports point of view remain relatively unexplored.

\section{Data and Methodology}

This paper estimates export creation and diversion patterns for all the FTAs/PTAs that Pakistan has signed to date, for 88 industries in which exports originated from Pakistan. We note that we have only included those industries for each FTA comparison that were granted concessions by FTA partners according to each agreement. This is because commodities for which concessions were not guaranteed are in the same league as commodities exported to MFN countries since they bear the same customs duties. We look at all those industries for which data was available for at least four years post-FTA as otherwise the results would be distorted in the presence of small outliers.

The data used to estimate the change in exports is taken from the United Nations Commodity Trade Statistics (UN Comtrade) database. We use data from 2003 to 2017 on the basis of the harmonized system two-digit commodity level. We start with 2003 because most of Pakistan's trade agreements were initiated after 2006. The MFN partners included are those with whom Pakistan's share of exports is at least 1 percent of its total exports. We therefore estimate the change in exports with respect to Pakistan's top 15 MFN trading partners relative to its FTA partners.

The methodology we use is adapted from UNESCAP and entails calculating the change in exports with each FTA partner pre- and post-trade agreement. ${ }^{3}$ This methodology is used to estimate the absolute and percentage change in the value and quantity of exports and imports for one country or a group of countries. We use it to estimate the growth in value of exports for Pakistan. The change is calculated in absolute as well as percentage terms. The change in exports for each year is summed to obtain the net change in exports over time. In the same way, the average annual percentage change in exports is estimated pre- and post-FTA.

\footnotetext{
${ }^{3}$ https://artnet.unescap.org/APTIAD/Export\%20growth.pdf
} 


$$
\sum_{i=1}^{99} \Delta \operatorname{exports}_{i F T A}+\sum_{i=1}^{99} \Delta \operatorname{exports}_{i M F N}=\text { total net } \text { change }
$$

where

- $\quad$ exports $_{i F T A}=$ sum of change in exports for all years for commodity $i$ with FTA partners (a)

- $\Delta$ exports $_{i M F N}=$ sum of change in exports for all years for commodity $i$ with MFN partners (b)

- Total net change $=$ difference between $(a)$ and $(b)$

If the total net change in industry $i$ is positive, then the result will be export creation. The rationale for this is that a positive net change indicates a higher increase in export proceeds with respect to at least one group of partners (FTA or MFN) even if there is a decrease in export proceeds with respect to another group of partners. Similarly, if the total net change in industry $i$ is negative, then this indicates export diversion. Intuitively, the sign of the change in exports to the FTA partner should be positive because FTAs presumably boost exports. However, it is also possible that the exports of a given industry have decreased with respect to the FTA partner and thus the sign may become negative. In such a scenario, we may find that the export creation in that industry was not due to the FTA but due to an increase in exports to an MFN partner.

Additionally, we run a difference-in-difference model to find out whether exports to FTA partners increased or decreased after they were "treated" with the FTA, compared to the control group of MFN partners that were not treated with an FTA. The control group includes the same top 15 MFN partners that account for 75 percent of Pakistan's total exports. The treated group of FTA/PTA partners includes only those industries that were part of the concessional list in each respective FTA/PTA. Dummy variables for time and treatment and an interaction term for time and treatment are used to calculate the extent to which exports to each FTA/PTA partner increased after the trade agreement, compared to the MFN partners.

The data on trade volumes is taken from UN Comtrade for the period 2003 to 2016 for both FTA and MFN partners. The nontreated years for each FTA/PTA partner vary according to the timing of the trade agreement: for example, for SAFTA, the nontreated years are 2003-06 while for Malaysia, the nontreated years are 2003-07. Details are given in the Appendix. 


\section{Results and Discussion}

Table A.1 in the Appendix lists the periods analyzed as pre- and post-trade agreement periods for each FTA/PTA partner. The net change in exports for the pre-FTA period is estimated to determine the trend in exports. This way, we control for the probability that an increase in exports was not due to the FTA but due to a linear increasing trend. Table A.2 in the Appendix lists the MFN partners included in this study. Since the first FTA was implemented with Sri Lanka in 2005, we analyze exports to MFN partners for 2005-17 for a comparison with the post-FTA exports to Pakistan's FTA partners. We do not analyze exports to MFN partners prior to 2006 because during the pre-FTA period, exports to FTA and MFN partners were independent of each other.

\subsection{Cumulative Change in Exports with FTA Partners}

We find that the cumulative net gain in export value with respect to all FTA partners over 10 years was USD3.5 billion, with annual average growth of 164 percent. This averages to a relatively small annual increase of USD350 million, approximately equal to 1.4 percent of Pakistan's total merchandise exports.

Table 1 shows the cumulative change in exports to FTA partners after the implementation of the FTA. The highest absolute gain in exports is in cotton to the tune of USD521 million. Pakistan's total goods exports were recorded at USD24.5 billion in 2017/18, out of which textile exports stood at USD13.3 billion, ${ }^{4}$ contributing nearly 60 percent to total goods exports. The textiles sector contributes 8.5 percent to the national GDP and provides employment to 35 percent of the country's labor force. In the textiles category, exports of cotton were nearly USD3.5 billion in 2017, making it the second largest export commodity after textile made-up articles whose exports stood at USD3.9 billion. Pakistan is the fourth largest producer of cotton and has the third largest spinning capacity in Asia, with only China and India ahead (Mirza, 2018).

This shows why cotton has the highest net gain-its exports were already at a higher level compared to other industries. After the FTA was implemented, Pakistan was unable to efficiently increase its exports of cotton. Instead, exports remained virtually stagnant. Since the value of cotton exports was highest - at about 30 percent of total goods exports, while

\footnotetext{
${ }^{4}$ Data from the State Bank of Pakistan for 2018.
} 
the remaining 98 industries accounted for 70 percent of goods exports-a small increase in cotton exports made it the top beneficiary of FTAs.

Table 1: Cumulative change in exports to FTA partners: Industry level

USD ‘000

\begin{tabular}{|c|c|c|}
\hline \multirow[t]{2}{*}{ Industry description } & \multicolumn{2}{|c|}{ Absolute change and annual average growth rate } \\
\hline & Pre-FTA & Post-FTA \\
\hline Aircraft, spacecraft and parts thereof & -1 & -4 \\
\hline $\begin{array}{l}\text { Albuminoidal substances, modified } \\
\text { starches, glues }\end{array}$ & -96 & 40 \\
\hline Aluminum and articles thereof & 5,099 & $-5,711$ \\
\hline Animal or vegetable fats and oils & 54 & 1,250 \\
\hline Animal-originated products, NES & 443 & -10 \\
\hline Animals, live & Nil & -2 \\
\hline $\begin{array}{l}\text { Apparel and clothing accessories, } \\
\text { knitted or crocheted }\end{array}$ & 2,959 & 20,319 \\
\hline $\begin{array}{l}\text { Apparel and clothing accessories, not } \\
\text { knitted or crocheted }\end{array}$ & 1,523 & 19,119 \\
\hline $\begin{array}{l}\text { Arms and ammunition, parts and } \\
\text { accessories }\end{array}$ & Nil & 132 \\
\hline Articles of leather & 22,435 & $-10,011$ \\
\hline Beverages, spirits and vinegar & Nil & 13,465 \\
\hline $\begin{array}{l}\text { Carpets and other textile floor } \\
\text { coverings }\end{array}$ & Nil & 25 \\
\hline Ceramic products & 14 & -109 \\
\hline Chemical products NES & 46 & 1,426 \\
\hline Clocks and watches and parts & 1,671 & 24,290 \\
\hline Cocoa and cocoa preparations & -139 & -29 \\
\hline Coffee, tea, mate and spices & 2,546 & -312 \\
\hline $\begin{array}{l}\text { Commodities not specified according } \\
\text { to kind }\end{array}$ & 186 & 36 \\
\hline Copper and articles thereof & 6,466 & 3,038 \\
\hline Cotton & 361,068 & 512,190 \\
\hline Dairy products & Nil & 243 \\
\hline $\begin{array}{l}\text { Electrical machinery and equipment } \\
\text { and parts thereof }\end{array}$ & 5,047 & 4,208 \\
\hline Essential oils & 192 & 648 \\
\hline Explosives & 37 & -20 \\
\hline Fabrics, knitted or crocheted & 11,675 & $-2,550$ \\
\hline Fabrics, special woven fabrics & 307 & 307 \\
\hline Fish & 9,003 & 16,511 \\
\hline $\begin{array}{l}\text { Food industries, residues and wastes } \\
\text { thereof }\end{array}$ & -114 & 12,845 \\
\hline Footwear & -82 & 572 \\
\hline Fruits and nuts & 12,581 & 96,547 \\
\hline Fur skins and artificial fur & Nil & 28 \\
\hline
\end{tabular}




\begin{tabular}{|c|c|c|}
\hline \multirow[t]{2}{*}{ Industry description } & \multicolumn{2}{|c|}{ Absolute change and annual average growth rate } \\
\hline & Pre-FTA & Post-FTA \\
\hline Glass and glassware & 2,322 & 3,854 \\
\hline Headgear and parts & 0.4 & 2 \\
\hline Inorganic chemicals & 743 & 8,364 \\
\hline Iron and steel & -310 & 3,486 \\
\hline Iron or steel articles & 5,964 & 17,779 \\
\hline Lac, gums and resins & 829 & 1,959 \\
\hline Lead and articles thereof & Nil & $-3,302$ \\
\hline $\begin{array}{l}\text { Machinery, mechanical appliances } \\
\text { and nuclear reactors }\end{array}$ & 47 & -17 \\
\hline Malt, starches, inulin, wheat gluten & 12,855 & $-13,714$ \\
\hline Manmade filaments & $-10,866$ & $-4,222$ \\
\hline Manmade staple fibers & 25,059 & $-15,599$ \\
\hline Meat and fish preparations & Nil & -941 \\
\hline Meat and edible meat & -7 & 69 \\
\hline Medical or surgical instruments & Nil & $-30,139$ \\
\hline $\begin{array}{l}\text { Metal, miscellaneous products of } \\
\text { base metal }\end{array}$ & 1,278 & 2,061 \\
\hline $\begin{array}{l}\text { Mineral fuels, mineral oils and } \\
\text { products of their distillation }\end{array}$ & 155,320 & $-73,999$ \\
\hline Miscellaneous edible preparations & -153 & 2,213 \\
\hline Miscellaneous manufactured articles & -402 & 6,359 \\
\hline Nickel and articles thereof & Nil & 64 \\
\hline Oil seeds & 2,468 & $-1,841$ \\
\hline Ores, slag and ash & 23,085 & $-4,901$ \\
\hline Organic chemicals & 18,897 & 7,494 \\
\hline Paper and paperboard & 104 & 21,637 \\
\hline Pharmaceutical products & 3,707 & 15,366 \\
\hline $\begin{array}{l}\text { Photographic or cinematographic } \\
\text { goods }\end{array}$ & -122 & -43 \\
\hline Plastics and articles thereof & $-3,537$ & 16,585 \\
\hline Precious metals and stones & 124 & 1,222 \\
\hline $\begin{array}{l}\text { Preparations of cereals, flour, starch } \\
\text { or milk }\end{array}$ & -631 & 890 \\
\hline Preparations of vegetables, fruit, nuts & 683 & 1,370 \\
\hline Printed books and newspapers & 136 & 598 \\
\hline Railway and parts thereof & 5,099 & $-4,348$ \\
\hline Raw hides, skins and leather & 18,155 & 33,350 \\
\hline Rice and cereals & 49,977 & 68,593 \\
\hline Rubber and articles thereof & 607 & 3,066 \\
\hline Salt, sulfur and stones & -851 & 153,371 \\
\hline Ships, boats and floating structures & Nil & -26 \\
\hline Silk & Nil & -19 \\
\hline $\begin{array}{l}\text { Soap, washing, polishing and } \\
\text { lubricating }\end{array}$ & -114 & 1,244 \\
\hline
\end{tabular}




\begin{tabular}{lcc}
\hline Industry description & Absolute change and annual average growth rate \\
\cline { 2 - 3 } & Pre-FTA & Post-FTA \\
\hline Stone, plaster, cement and articles & 1,475 & 347 \\
Sugars and sugar confectionery & $-6,097$ & -112 \\
Tanning or dyeing extract & 1,284 & 2,024 \\
Textile fabric & 705 & 300 \\
Textiles, made-up articles & $-2,627$ & 27,164 \\
Tobacco & 1,346 & 348 \\
Tools and cutlery & Nil & -522 \\
Toys, games and sports requisites & -47 & 225 \\
Trees and other plants & Nil & 51 \\
Vegetable products, NES & -730 & 28,243 \\
Vegetable textile fibers, paper yarn & 6,245 & $-3,833$ \\
Vegetables & 28,149 & -446 \\
Vehicles and parts, accessories & Nil & -11 \\
thereof & & \\
Waddings, rope, cable & 79 & 1,426 \\
Wood and articles of wood & 18 & 81 \\
Wood pulp & Nil & -21 \\
Wool & Nil & -115 \\
Works of art; collectors' pieces and & 376 & -631 \\
antiques & & \\
Zinc and articles thereof & Nil & 14 \\
\hline
\end{tabular}

Note: Percentage change in parentheses.

Source: Authors' calculations.

After cotton, the second highest net gain in export value was for salt, sulfur and stones. The main commodities in this industry are cement, marble and granite. This industry had a negative net change pre-FTA, but grew at an average rate of 78 percent and gained an additional USD153 million after the FTAs. In this way, salt, sulfur and stone, an industry with a less than 2 percent share of Pakistan's total goods exports, was a major beneficiary of the FTAs and PTAs. The fruits and nuts industry comes third, with a net change in export value of USD96 million and 45 percent annual average growth. Pakistan has rich pomological resources and its fruits are in demand in various parts of the world, especially mango, citrus and apples. Pakistan's total exports of fruits and nuts in 2017 were USD353 million, making the industry's share close to 1.4 percent of total exports.

The highest average growth rate post-FTA was estimated to be in precious metals, and food, residues and wastes, both growing at more than 1,000 percent. Both industries had negative growth pre-FTA but high positive growth post-FTA, indicating the significant benefit these relatively small commodities gained. Edible meat and fur skin grew at an average of 
883 and 748 percent, respectively, although the entire gain in edible meat came from exports to China since Pakistan did not export this commodity to any other FTA partner. The second largest export industry, cereals and rice, which brought in around USD1.75 billion in 2017, was also a beneficiary of FTAs, gaining a net USD68 million with respect to Pakistan's FTA partners and witnessing a 69 percent growth rate.

Industries that lost significantly in terms of export value include vegetable textile fiber, fur skins, ships and boats, manmade staple fibers, meats not elsewhere classified, and aircrafts. Almost all these industries have a very small share in total goods exports, ranging from 0.0001 percent to 0.1 percent. This implies that the main losers post-FTA were commodities in which Pakistan's exports are negligible. Other major export sectors, such as medical or surgical instruments and articles of leather, whose share of exports is close to 2 percent, show mixed results. The medical or surgical instruments industry gained and grew at 24 percent while articles of leather grew at 108 percent but lost in terms of export value. Another major export sector, sports goods, also witnessed positive growth in exports. Similarly, vegetables not elsewhere classified had an average growth rate of 363 percent and gained in terms of export value.

Figure 1: Net change in exports to FTA partners, 2007-16

USD ‘000

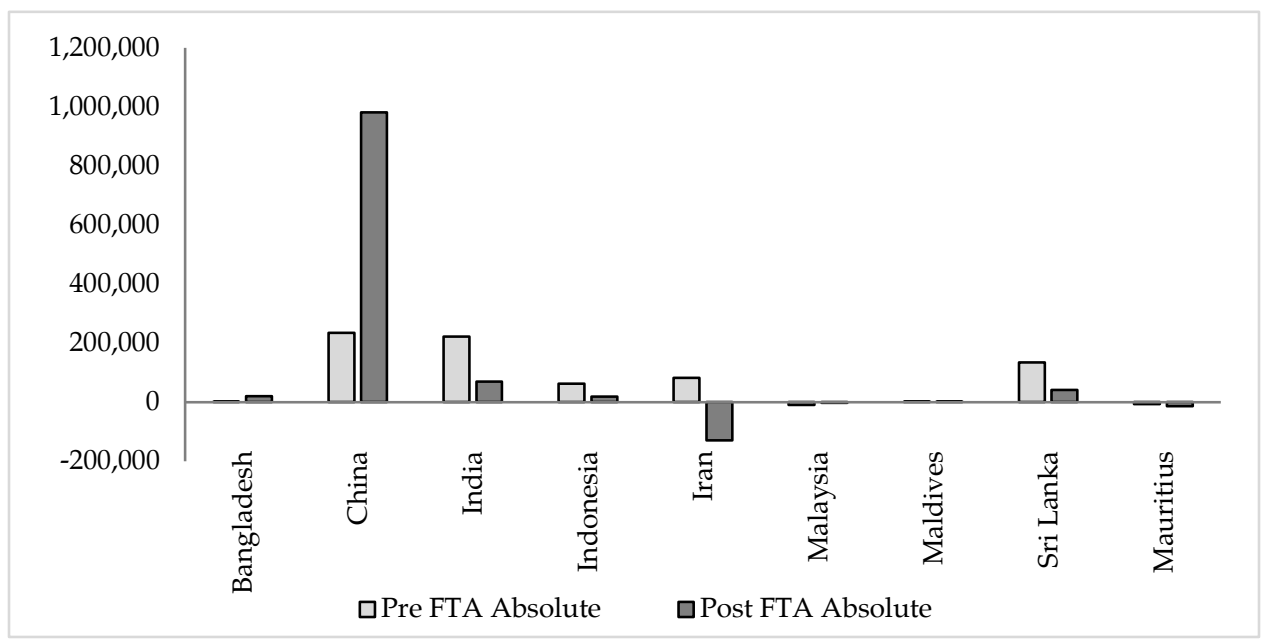

Source: Authors' calculations.

Figure 1 above and Figure 2 below illustrate the partner-level net change in exports pre- and post-FTA in absolute and percentage terms for the overall period. We can see that, after the implementation of FTAs and 
PTAs, the net change in export value was negative for Iran, Malaysia and Mauritius but positive for other FTA partners. This implies that trade agreements have remained beneficial as net exports increased with respect to six out of nine FTA partners. The negative net change implies that the real benefit of these trade agreements was not attained after the FTAs and that exports witnessed a net decline over the years rather than increasing. The highest net absolute increase in exports was recorded with respect to China, followed by India and Sri Lanka. The highest net decline in exports was recorded with respect to Iran, followed by Mauritius and Malaysia.

Figure 2: Net percentage change in exports to FTA partners, 2007-16

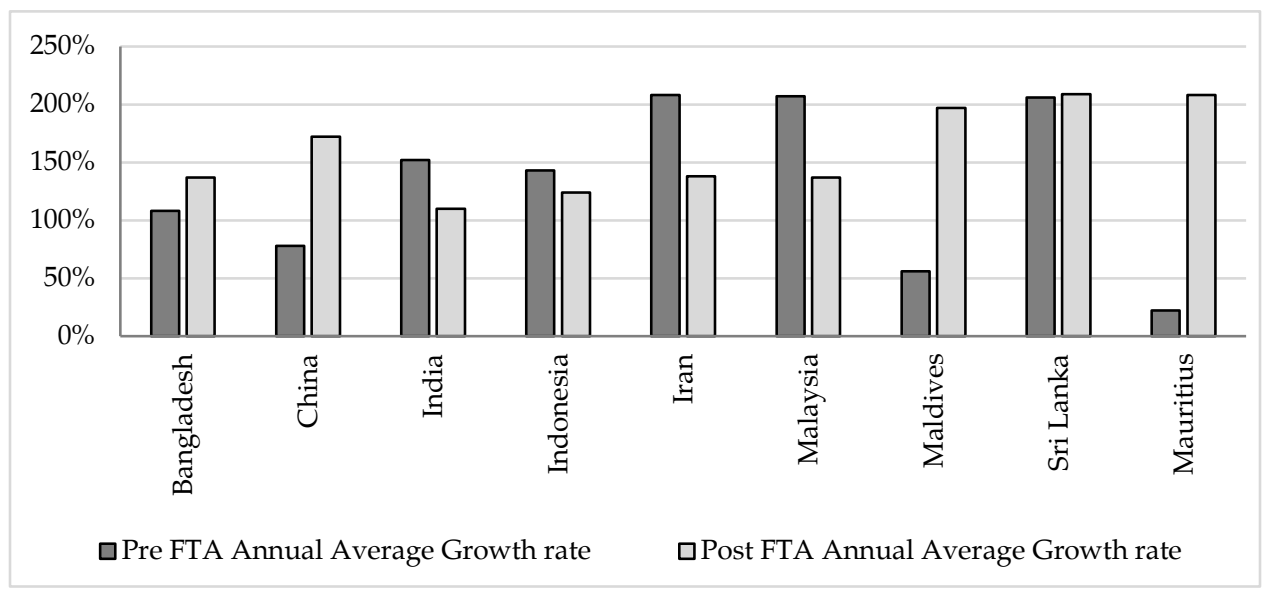

Source: Authors' calculations.

\subsection{Overall Results for Export-Creating and Diverting Industries}

A comparison of the net change in Pakistan's exports to MFN and FTA partners helps identify export creation and diversion. Table 2 gives the overall results for export creation, diversion and decline. Among exportcreating industries, we see a net increase of USD3 billion in exports to the top 15 MFN partners and, simultaneously, a net increase of USD1.1 billion with respect to the country's FTA partners in 45 industries. The total value of exports created during this period is USD4.1 billion.

The net increase in exports to nine FTA partners over the decade is nominal, indicating the very low levels of trade that Pakistan maintains with its neighbors, especially its South Asian trading partners. The net increase with respect to MFN partners was almost three times that of the country's FTA partners even though Pakistani exports are affected by the customs duties levied by its MFN partners. This implies either that Pakistan's exports 
are uncompetitive in the FTA countries or that it has been unable to tap the potential of these markets by failing to identify primary sources of demand.

Table 2: Overall results for exports creation and diversion, 2007-16

\begin{tabular}{lccc}
\hline & $\begin{array}{c}\text { Net change in } \\
\text { export-creating } \\
\text { industries }\end{array}$ & $\begin{array}{c}\text { Net change in } \\
\text { export-diverting } \\
\text { industries }\end{array}$ & $\begin{array}{c}\text { Net change in } \\
\text { export-declining } \\
\text { industries }\end{array}$ \\
\hline FTA partners & $1,137,528$ & 12,788 & $-152,060$ \\
MFN partners & $3,028,727$ & $-150,611$ & $-355,958$ \\
Sum of FTA and MFN & $4,161,330$ & $-137,823$ & $-508,018$ \\
Total no. of industries & 45 & 10 & 33 \\
\hline
\end{tabular}

Source: Authors' calculations.

In export-diverting industries, the net change in exports to MFN partners was -USD150 million, while the net change with respect to FTA partners was USD12 million, bringing the total net decrease in exports to USD137 million across 10 industries. The net change with respect to MFN partners is an estimated -USD355 million, while the net change with respect to FTA partners is an estimated -USD158 million, bringing the net decline to USD508 million. The total net export creation post-FTA, after subtracting the decline in exports and gross/net decline, is USD3.5 billion or, on average, USD350 million annually. This accounts for about 1.4 percent of Pakistan's total annual goods exports, implying that the benefits of the FTAs were very small and did not account for major export growth even though all the FTA partners, barring one, belong to the same region, and, according to the gravity model, should lead to higher levels of bilateral trade.

The results suggest that we can reject our null hypothesis because 45 out of a total of 88 industries (51 percent of the sample) experienced export creation while only 10 industries (11 percent) experienced export diversion. Further, in 33 industries (38 percent), the net change in exports to FTA partners was negative; this cannot be termed export creation or diversion, rather it denotes a decline in exports to FTA partners even after the implementation of the agreements. Since a small majority of these industries are found to have created exports, we accept the alternative hypothesis that Pakistan's bilateral and multilateral trade agreements have led primarily to export creation. 


\subsection{Detailed Results for Export-Creating and Diverting Industries}

This section discusses in detail those industries that have performed well or poorly by merging them into broad sectors. Tables 3 and 4 give our findings for the textiles sector, which includes 16 industries. We find that knitted apparel, not-knitted apparel, made-up articles and cotton account for the highest export creation. Interestingly, these industries are also among Pakistan's top five export industry groups. However, these four are the only export-creating industries in the textiles sector, as all other textile groups are either export diverting or declining. Cotton and the other three textile sectors have achieved large-scale export creation, albeit at the cost of huge public subsidies and export incentives.

Table 3: Export-creating industries: Textiles

\begin{tabular}{lccc} 
& & & USD ‘000 \\
\hline Industry description & $\begin{array}{c}\text { All MFN } \\
\text { partners }\end{array}$ & $\begin{array}{c}\text { All FTA } \\
\text { partners }\end{array}$ & $\begin{array}{c}\text { Total net } \\
\text { change }\end{array}$ \\
\hline Cotton & $-321,191$ & 512,190 & 190,999 \\
$\begin{array}{l}\text { Apparel and clothing accessories; } \\
\text { knitted }\end{array}$ & 778,109 & 20,319 & 798,428 \\
$\begin{array}{l}\text { Apparel and clothing accessories; } \\
\text { not knitted }\end{array}$ & 759,319 & 19,119 & 778,438 \\
$\begin{array}{l}\text { Headgear and parts } \\
\text { Raw hides, skins and leather }\end{array}$ & 508 & 2 & 510 \\
Tanning or dyeing extract & 8,855 & 33,350 & 42,205 \\
Textiles, made-up articles & 464 & 2,024 & 2,488 \\
\hline
\end{tabular}

Source: Authors' calculations.

Table 4: Export-diverting/declining industries: Textiles

\begin{tabular}{lccc} 
& & & USD ’000 \\
\hline Industry description & All MFN partners & All FTA partners & Net change \\
\hline Articles of leather & $-26,240$ & $-10,011$ & $-36,251$ \\
Carpets & $-157,081$ & -860 & $-157,941$ \\
Fabrics; knitted & $-15,638$ & $-2,550$ & $-18,188$ \\
Fur skins & 218 & 28 & 246 \\
Manmade filaments & $-127,032$ & $-4,222$ & $-131,254$ \\
Manmade staple fibers & 45,313 & $-15,599$ & 29,713 \\
Silk & 289 & -19 & 270 \\
Vegetable textile fibers & -396 & $-3,833$ & $-4,228$ \\
Wool & 542 & -115 & 427 \\
\hline
\end{tabular}

Source: Authors' calculations.

Pakistan's main subsidized export sectors include textiles, carpets, surgical instruments, sports goods, sugar, and leather. Combining these 
subsidies implies that the government is providing export subsidies equal to USD725 million annually (Qarni, 2018). Currently, the government gives about USD260 million annually in cash subsidies to textile exporters, while subsidized energy rates are another incentive. Until 2017, the government was providing cash subsidies equal to 4 percent of exports for yarn and fabric, 5 percent for processed fabric, 6 percent for made-up articles, and 7 percent for garments (knitted apparel). In addition, a discounted tariff of up to PKR3 was charged to export-oriented industries (Khan, 2018).

In the presence of such incentives, the positive performance of only four out of a total of ten textile groups implies that the at-par subsidy policy for the industry is not an optimal use of taxpayers' resources. The four export-creating textile groups-knitted apparel, not-knitted apparel, made-up articles, and cotton-should be the focus of government incentives. Diverting subsidies from unproductive groups to these productive groups would enhance their export potential; the resulting increase in exports would not only benefit the external account, but also create domestic employment.

The other subsidized industry that has experienced export creation is surgical instruments, which is concentrated in the Sialkot district. In 2017, its total exports were USD410 million, equivalent to about 2 percent of Pakistan's total goods exports. Surgical instruments performed better than cotton in the sense that exports to MFN partners did not fall and there was a significant increase in exports to both FTA and MFN partners; the total value of exports created was about USD152 million. In the category of basic metals, iron and steel, lead, and copper accounted for export creation, while furniture and mechanical appliances were two other major industries that experienced export creation.

A major subsidized industry, articles of leather, registered a net decline of USD36 million. The leather industry is given a 3 percent duty drawback subsidy on imports of raw material. An additional 2 percent duty drawback is given if the export is to a nontraditional market. Further, to encourage finished leather exports instead of raw hides, the government has allowed the duty-free import of tanning machinery and has taxed exports of raw skins. Having availed these incentives, the industry's performance should have experienced more positive gains.

Tables 5 and 6 show the performance of food and beverages (all edible items). Our findings reveal that 15 out of 23 industries experienced export creation, in particular rice, fish, meat, fruits and nuts, vegetable 
products, spices, animal and vegetable oils, beverages, and tobacco. The highest level of export creation occurred in rice, followed by beverages and fish. It can be argued that these industries produce a sufficient export surplus and were able to sustain the additional demand post-FTA, thereby benefitting the economy by bringing in foreign exchange proceeds from MFN and FTA partners despite little or no export subsidies and support from the government (Haque \& Kemal, 2007).

The only subsidized industry in this sector, sugar and sugar confectionery, recorded an estimated gross decline of USD58 million, with rising exports to MFN partners but declining exports to FTA partners. The world price of sugar in 2017 was USD383 per tonne, while in Pakistan it was USD480. To fill this price gap, the government gave sugar mills a subsidy of about USD0.1 per kilogram to enhance exports. The total subsidy was USD200 million, which is 200 percent higher than the USD65 million subsidy given in 2015. The fall in exports to FTA partners suggests that sugar from Pakistan is not competitive in FTA markets, despite strong price supports from the government; this indicates serious issues dometically (Zaidi, 2018).

Table 5: Export-creating industries: Foods and beverages

\begin{tabular}{lccc} 
& All FTA & USD `000 \\
\hline Industry description & $\begin{array}{c}\text { All MFN } \\
\text { partners }\end{array}$ & $\begin{array}{c}\text { Total net } \\
\text { change }\end{array}$ \\
\hline Animal or vegetable fats and oils & 878 & 1,250 & 2,128 \\
Beverages, spirits and vinegar & 201,237 & 13,465 & 214,702 \\
Dairy products & 8,235 & 243 & 8,478 \\
Essential oils & 785 & 648 & 1,433 \\
Fish & 109,248 & 16,511 & 125,759 \\
Food industries, residues and wastes & 7,903 & 12,845 & 20,748 \\
thereof & & & \\
Fruits and nuts & 982 & 96,549 & 97,531 \\
Meat and edible meat & 128,252 & 69 & 128,321 \\
Miscellaneous edible preparations & 3,858 & 2,213 & 6,071 \\
Preparations of cereals, flour, starch & 13,871 & 1,126 & 14,997 \\
or milk & & & \\
Preparations of vegetables, fruit, nuts & 21,213 & 1,370 & 22,583 \\
Rice and cereals & 213,680 & 68,593 & 282,273 \\
Tobacco & 4,583 & 348 & 4,932 \\
Vegetable products, not else specified & 2,550 & 28,243 & 30,793 \\
Vegetables & 6,188 & 847 & 7,035 \\
\hline
\end{tabular}

Source: Authors' calculations. 
Table 6: Export-diverting/declining industries: Foods and beverages

\begin{tabular}{lccc}
\hline Industry description & $\begin{array}{c}\text { All MFN } \\
\text { partners }\end{array}$ & $\begin{array}{c}\text { All FTA } \\
\text { partners }\end{array}$ & Net change \\
\hline Animal-originated products, NES & 1,625 & -823 & 803 \\
Animals; live & 4,014 & -2 & 4,012 \\
Cocoa and cocoa preparations & -340 & -29 & -369 \\
Coffee, tea, mate and spices & 51,347 & -312 & 51,035 \\
Meat and fish preparations & $-5,333$ & -607 & $-5,941$ \\
Oil seeds & 24,065 & $-1,841$ & 22,223 \\
Malt, starches, wheat gluten & 4,061 & $-13,714$ & $-9,653$ \\
Sugars and sugar confectionery & 58,180 & -112 & 58,068 \\
\hline
\end{tabular}

Source: Authors' calculations.

Tables 7 and 8 show the performance of industries in the machinery and equipment sector. The other subsidized industry that showed export creation is surgical instruments: its total annual exports account for only 2 percent, but its efforts increased on net. The highest level of export diversion in all sectors was in the sports goods industry, which is also concentrated in Sialkot and is among the five major subsidized industries of Pakistan.

Table 7: Export-creating industries: Machinery and equipment

\begin{tabular}{lccc}
\hline Industry description & $\begin{array}{c}\text { All MFN } \\
\text { partners }\end{array}$ & $\begin{array}{c}\text { All FTA } \\
\text { partners }\end{array}$ & $\begin{array}{c}\text { Total net } \\
\text { change }\end{array}$ \\
\hline Machinery, mechanical appliances and & 51,144 & 4,208 & 55,352 \\
nuclear reactors & & & \\
Medical or surgical instruments & 128,587 & 24,290 & 152,877 \\
Miscellaneous manufactured articles & 21,988 & 748 & 22,735 \\
Musical instruments and parts & 376 & 132 & 508 \\
Tools and cutlery & 36,049 & 2,061 & 38,110 \\
\hline
\end{tabular}

Source: Authors' calculations. 
Table 8: Export-diverting/declining industries: Machinery and equipment

USD ‘000

\begin{tabular}{llll}
\hline Industry description & $\begin{array}{l}\text { All MFN } \\
\text { partners }\end{array}$ & $\begin{array}{l}\text { All FTA } \\
\text { partners }\end{array}$ & Net change \\
\hline Aircraft and parts thereof & 4,855 & $-1,353$ & 3,502 \\
Ceramic products & $-1,600$ & -109 & $-1,709$ \\
Electrical machinery and equipment & 1,617 & -17 & 1,600 \\
Explosives & -835 & -625 & $-1,460$ \\
Photographic or cinematographic & 1,708 & -43 & 1,665 \\
goods & & & \\
Railway and parts thereof & $-36,199$ & $-4,348$ & $-40,547$ \\
Ships, boats and floating structures & 1100 & -26 & 1,074 \\
Vehicles and parts, accessories thereof & 3,072 & -11 & 3,061 \\
Sports goods & $-62,777$ & 6,359 & $-56,418$ \\
\hline
\end{tabular}

Source: Authors' calculations.

Tables 9 and 10 show the performance of industries in the metals and minerals sector. Salt and sulfur, followed by copper, recorded the highest levels of export creation, while other basic metals such as iron and lead also experienced export creation. The highest decline in exports was in mineral fuels, with further export diversion in aluminum and nickel.

Table 9: Export-creating industries: Metals and minerals

\begin{tabular}{llll}
\hline Industry description & $\begin{array}{c}\text { All MFN } \\
\text { partners }\end{array}$ & $\begin{array}{l}\text { All FTA } \\
\text { partners }\end{array}$ & $\begin{array}{c}\text { Total net } \\
\text { change }\end{array}$ \\
\hline Chemical products NES & 2,452 & 1,426 & 3,878 \\
Copper and articles thereof & 48,975 & 3,038 & 52,014 \\
Precious metals and stones & 2625 & 1,222 & 3,846 \\
Stone, plaster, cement and articles & 1,445 & 347 & 1,792 \\
Salt, sulfur and stones & 75,646 & 150,525 & 226,171 \\
Inorganic chemicals & $-2,542$ & 8,364 & 5,822 \\
Iron and steel & 13,069 & 3486 & 16,555 \\
Iron or steel articles & 2,110 & 17779 & 19,889 \\
Lac, gums and resins & 2,600 & 1,959 & 4,559 \\
Lead and articles thereof & 1,837 & 14 & 1,851 \\
\hline
\end{tabular}

Source: Authors' calculations. 
Table 10: Export-diverting/declining industries: Metals and minerals

\begin{tabular}{llll} 
& & & USD ’000 \\
\hline \multicolumn{1}{c}{ Industry description } & $\begin{array}{l}\text { All MFN } \\
\text { partners }\end{array}$ & $\begin{array}{c}\text { All FTA } \\
\text { partners }\end{array}$ & $\begin{array}{c}\text { Total net } \\
\text { change }\end{array}$ \\
\hline $\begin{array}{l}\text { Aluminum and articles thereof } \\
\text { Metal; miscellaneous products of base }\end{array}$ & 7,264 & -604 & 6,660 \\
metal & 546 & -522 & 24 \\
$\begin{array}{l}\text { Metals; NES, cermet and articles thereof } \\
\text { Mineral fuels, mineral oils and their }\end{array}$ & 496 & $-3,302$ & $-2,806$ \\
$\begin{array}{l}\text { products } \\
\text { Nickel and articles thereof }\end{array}$ & $-196,528$ & $-73,999$ & $-270,527$ \\
$\begin{array}{l}\text { Ores, slag and ash } \\
\text { Organic chemicals }\end{array}$ & 1,629 & -64 & 1,565 \\
Wood pulp & 373 & $-4,901$ & $-4,528$ \\
\hline
\end{tabular}

Source: Authors' estimates.

Table 11 shows the extent of export creation in miscellaneous industries. The highest level of export creation was in plastics, followed by furniture, paper, and pharmaceutical industries.

Table 11: Export-creating industries: Miscellaneous items

\begin{tabular}{llll}
\hline \multicolumn{1}{c}{ Industry description } & $\begin{array}{c}\text { Top 15 MFN } \\
\text { partners }\end{array}$ & $\begin{array}{c}\text { All FTA } \\
\text { partners }\end{array}$ & $\begin{array}{c}\text { Total net } \\
\text { change }\end{array}$ \\
\hline Furniture; bedding, mattresses & 32,388 & 225 & 32,613 \\
Glass and glassware & 640 & 3,854 & 4,494 \\
Paper and paperboard & 7614 & 21,637 & 29,252 \\
Pharmaceutical products & 9,560 & 15,366 & 24,926 \\
Plastics and articles thereof & 20,121 & 16,585 & 36,706 \\
Soap, washing, polishing and lubricating & -220 & 1,244 & 1,024 \\
Trees and other plants & 1,037 & 51 & 1,088 \\
Works of art; collectors' pieces and & 16 & 2 & 18 \\
antiques & & & \\
\hline
\end{tabular}

Source: Authors' estimates.

The FTAs and PTAs implemented by Pakistan were nominally successful in enhancing its export base. Our findings suggest that about half of industries sustained a sufficient export surplus since they were able to continue exporting to MFN partners while meeting the increased demand from FTA partners. For the remaining 33 industries, the factors responsible for export diversion or a gross/net decline in exports may be internal or external and require further attention from policymakers. 


\subsection{Pakistan's Exports to FTA Partners: Difference-in-Difference Results}

Table 12 gives the results of a difference-in-difference estimation for exports to all nine FTA/PTA partners. Pakistan's exports to China in impacted sectors rose significantly relative to its MFN partners after the FTA was implemented, while overall exports to the latter increased over time after the Pakistan-China FTA. These results are similar to Chaudhry, Jamil and Chaudhry (2017) who also find that exports to China increased significantly post-FTA. Exports to Mauritius are significantly lower than to other MFN partners before the PTA, but rose significantly in impacted sectors after the Pakistan-Mauritius PTA was implemented.

In the case of SAFTA, exports to India, Bangladesh and the Maldives increased post-FTA compared to exports to Pakistan's MFN partners, although this increase is statistically insignificant. Exports to Sri Lanka fell to an insignificant degree after SAFTA was implemented. However, overall exports to all four SAFTA partners were significantly lower than those to MFN partners before SAFTA. Overall exports to Malaysia and Indonesia were significantly lower than to MFN partners before the respective FTAs were implemented, but exports to both countries decreased after the FTA, although this decrease remains insignificant. Further, overall exports to MFN partners also fell significantly over time. Exports to Iran were significantly lower than to MFN partners before the Pakistan-Iran PTA was implemented. Exports increased after the PTA but remain statistically insignificant. Exports to MFN partners fell significantly over time.

Table 12: Industry-level difference-in-difference analysis

\begin{tabular}{|c|c|c|c|c|c|c|c|c|c|}
\hline & \multicolumn{9}{|c|}{ Log of exports to } \\
\hline & Chi & a & $\begin{array}{c}\text { Sri } \\
\text { Lanka }\end{array}$ & $\begin{array}{c}\text { Bangla- } \\
\text { desh }\end{array}$ & Maldives & $\begin{array}{c}\text { Mauri- } \\
\text { tius }\end{array}$ & Mal & Iran & $\begin{array}{c}\text { Indone- } \\
\text { sia }\end{array}$ \\
\hline $\begin{array}{l}\text { Time*tre } \\
\text { tment }\end{array}$ & $\begin{array}{l}0.39^{*} \\
(0.23)\end{array}$ & $\begin{array}{l}0.03 \\
(0.25)\end{array}$ & $\begin{array}{l}-0.07 \\
(0.23)\end{array}$ & $\begin{array}{l}0.09 \\
(0.25)\end{array}$ & $\begin{array}{l}0.12 \\
(0.25)\end{array}$ & $\begin{array}{l}0.38^{*} \\
(0.22)\end{array}$ & $\begin{array}{l}-0.17 \\
(0.22)\end{array}$ & $\begin{array}{l}0.19 \\
(0.28)\end{array}$ & $\begin{array}{l}-0.06 \\
(0.28)\end{array}$ \\
\hline Treatment & $\begin{array}{l}\mathrm{t} 0.08 \\
(0.19)\end{array}$ & $\begin{array}{l}-0.26 \\
(0.21)\end{array}$ & $\begin{array}{l}-0.30^{* *} \\
(0.14)\end{array}$ & $\begin{array}{l}-0.77^{* * *} \\
(0.21)\end{array}$ & $\begin{array}{l}-2.0^{* * *} \\
(0.21)\end{array}$ & $\begin{array}{l}-1.5^{* * *} \\
(0.15)\end{array}$ & $\begin{array}{l}-0.4 \\
(0.15)\end{array}$ & $\begin{array}{l}-0.6^{* * * *} \\
(0.13)\end{array}$ & $\begin{array}{l}-0.65^{* * *} \\
(0.25)\end{array}$ \\
\hline me & $\begin{array}{l}0.21^{* * *} \\
(0.05)\end{array}$ & $\begin{array}{l}0.22^{* * *} \\
(0.26)\end{array}$ & $\begin{array}{l}-0.21^{* *} \\
(0.05)\end{array}$ & $\begin{array}{l}0.22^{* * *} \\
(0.06)\end{array}$ & $\begin{array}{l}0.22^{* * *} \\
(0.06)\end{array}$ & $\begin{array}{l}-0.2^{* * * *} \\
(0.05)\end{array}$ & $\begin{array}{l}-0.2^{* * *} \\
(-0.05) \\
\end{array}$ & $\begin{array}{l}-0.23^{* *} \\
(0.07) \\
\end{array}$ & $\begin{array}{l}-0.13^{* *} \\
(0.07) \\
\end{array}$ \\
\hline
\end{tabular}

Note: Standard errors in parentheses. Statistical significance: * at 10 percent, ${ }^{* *}$ at 5 percent, and ${ }^{* * *}$ at 1 percent level.

Source: Authors' estimates, using UN Comtrade data.

The difference-in-difference results support our earlier finding that Pakistan's FTAs and PTAs have been largely unsuccessful in increasing exports. Our export creation and diversion results show that only half the 
industries were able to create new exports for Pakistan, while the difference-in-difference results show that the major contributors to this export creation were China and Mauritius. Further, the findings reveal that exports to FTA/PTA partners even before the trade agreements were lower than to other trading partners and that not much has improved even after the trade agreements.

\section{Conclusion and Policy Implications}

While Pakistan has signed several bilateral trade agreements and one regional trade agreement to boost export growth, policymakers may not necessarily be concerned as to whether exports are actually growing or merely being diverted away from nonmember countries. The purpose of this paper was to distinguish between the gross increase in exports due to FTAs and net exports under FTAs. The net increase in FTAs helps us assess whether these agreements were able to create new exports for the country or if they just diverted exports from non-FTA partners.

Overall, Pakistan's trade agreements are deemed partly successful because 45 industries show export creation while 10 show export diversion. However, it is a matter of concern that 33 industries witnessed a fall in net exports to FTA partners or to both MFN and FTA partners.

The results indicate that all five export-oriented sectors, barring surgical instruments, witnessed export diversion, including most components of the textiles sector, which remains the largest recipient of export subsidies. Barring cotton, textiles and leather were the worst performing, followed by other subsidized industries including sugar and sports goods, which was unable to benefit from concessional trade as exports kept falling or being diverted.

The industries most successful in creating new exports for Pakistan

are associated primarily with the food and beverages sector, including vegetables, fish, dairy products, sugar, fruits and meat. This implies that the agriculture and livestock sector has immense potential for earning foreign exchange through exports. The results indicate that a shift in subsidies from export-diverting traditional export-oriented sectors toward export-creating sectors may be an important strategy.

The 33 industries identified as having declining net exports to both FTA and MFN partners are those that require serious attention from policymakers. Unless the factors associated with this decline in exports are 
addressed, adding these industries to FTAs will not bring about any gain. Similarly, negotiations for trade agreements should not be designed to target only the major industry groups. Rather, they should be more inclusive, given that many small industries are found to be export-creating while large industries may be export-diverting.

Before negotiating any new FTAs, it is important to revisit the existing ones and add export-creating industries to the concessions list. We also find that absolute fiscal incentives given to the major export-oriented industries have not yielded significant benefits. Instead, the government should prioritize those industries for export incentives and subsidies, which have been identified as export-creating but been neglected under previous export promotion policies.

Finally, the surgical instruments industry, concentrated in Sialkot as a cottage industry, is the only subsidized industry that is export-creating and has a positive net increase in exports to both MFN and FTA partners, even though its share of total exports is less than 2 percent. Policymakers should focus on the growth of this industry by providing special incentives, such as giving the existing Sialkot industrial cluster special economic zone status to enhance the vertical and horizontal linkages between firms. 


\section{References}

Ahmed, H., Hamid, N., \& Mahmud, M. (2013). Exports: Lessons from the past and the way forward. In R. Amjad \& S. J. Burki (Eds.), Pakistan: Moving the economy forward (chap. 6). Lahore School of Economics.

Aitken, N. D. (1973). The effect of the EEC and EFTA on European trade: A temporal cross-section analysis. American Economic Review, 63(5), 881-892.

Akhter, N., \& Ghani, E. (2010). Regional integration in South Asia: An analysis of trade flows using the gravity model. Pakistan Development Review, 49(2), 105-118.

Baier, S. L., \& Bergstrand, J. H. (2007). Do free trade agreements actually increase members' international trade? Journal of International Economics, 71, 72-95.

Bentick, B. L. (1963). Estimating trade creation and trade diversion. The Economic Journal, 73(290), 219-225.

Brada, J. C., \& Mendez, J. A. (1983). Economic integration among developed, developing and centrally planned economies: A comparative analysis. Review of Economics and Statistics, 67(4), 549556.

Caliendo, L., \& Parro, F. (2015). Estimates of the trade and welfare effects of NAFTA. Review of Economic Studies, 82(1), 1-44.

Carrere, C. (2003). Revisiting the effects of regional trade agreements on trade flows with proper specification of the gravity model (Working Paper No. 200310). Centre d'Études et de Recherches sur le Développement International.

Chaudhry, T., Jamil, N., \& Chaudhry, A. (2017). Pakistan's experience with the Pakistan-China FTA: Lessons for CPEC. Lahore Journal of Economics, 22, 1-24.

Chor, D. (2010). Unpacking sources of comparative advantage: A quantitative approach. Journal of International Economics, 82(2), 152167.

Costinot, A., Donaldson, D., \& Komunjer, I. (2012). What goods do countries trade? A quantitative exploration of Ricardo's ideas. Review of Economic Studies, 79(2), 581-608. 
Freund, C., \& Ornelas, E. (2010). Regional trade agreements (Policy Research Paper No. 5314). World Bank Group.

Haque, N., \& Kemal, A. (2007). Impact of export subsidies on Pakistan's exports (Working Paper No. 2007:26). Pakistan Institute of Development Economics.

Khan, Z. (2018). PM to announce export package worth Rs70bn today. Dawn. https://www.dawn.com/news/1307426

Magee, C. S. (2008). New measures of trade creation and trade diversion. Journal of International Economics, 75(2), 349-362.

Qarni, O. (2018). Textile producers expect further hike in exports. Express Tribune. https://tribune.com.pk/story/1725423/2-textileproducers-expect-hike-exports /

Soloaga, I., \& Winters, L. A. (2001). Regionalism in the nineties: What effect on trade? North American Journal of Economics and Finance, 12, 1-29.

Tinbergen, J. (1962). Shaping the world economy: Suggestions for an international economic policy. Twentieth Century Fund.

Viner, J. (1950). The customs union issue. Carnegie Endowment for International Peace.

Yeats, A. J. (1998). Does Mercosur's trade performance raise concerns about the effects of regional trade arrangements? World Bank Economic Review, 12(1), 1-28.

Zaidi, H. (2018). The political economy of export packages. Dawn. https://www.dawn.com/news/1413402 
Appendix

Table A1: Description of pre- and post-FTA/PTA periods analyzed

\begin{tabular}{lcc}
\hline FTA/PTA partner & Pre-FTA period (nontreated) & Post-FTA period (treated) \\
\hline SAFTA & $2003-2006$ & $2007-2017$ \\
China & $2003-2007$ & $2008-2017$ \\
Iran & $2003-2004$ & $2005-2017$ \\
Indonesia & $2009-2012$ & $2013-2017$ \\
Malaysia & $2003-2007$ & $2008-2017$ \\
Mauritius & $2003-2007$ & $2008-2017$ \\
Sri Lanka & $2003-2004$ & $2006-2017$ \\
\hline
\end{tabular}

Table A2: Description of MFN partners and periods analyzed

\begin{tabular}{lc}
\hline MFN partner & Export period analyzed \\
\hline Australia & $2005-2017$ \\
Belgium & $2005-2017$ \\
France & $2005-2017$ \\
Germany & $2005-2017$ \\
Italy & $2005-2017$ \\
Kenya & $2005-2017$ \\
Kingdom of Saudi Arabia & $2005-2017$ \\
The Netherlands & $2005-2017$ \\
South Korea & $2005-2017$ \\
Spain & $2005-2017$ \\
Turkey & $2005-2017$ \\
United Arab Emirates & $2005-2017$ \\
United Kingdom & $2005-2017$ \\
United States of America & $2005-2017$ \\
Vietnam & $2005-2017$ \\
\hline
\end{tabular}

